\title{
Theory and Methodology of Rational Financing at Subfederal Level
}

\author{
Bubnov Vyacheslav \\ Federal State Budgetary Educational Institution "Irkutsk \\ State Transport University" \\ (FSBEI HE ISTU) \\ Irkutsk, the Russian Federation \\ Bubnovva13@gmail.com
}

\author{
Yakhno Tatyana \\ Federal State Budgetary Educational Institution "Irkutsk \\ State Transport University" \\ (FSBEI HE ISTU) \\ Irkutsk, the Russian Federation \\ avistas@yandex.ru
}

\begin{abstract}
Financing of economic growth and economic development at the subfederal level due to the limited financial resources is considered; the regularity of the formation of a new financial instrument - rational financing - is justified. The concept of rational financing has been formed from the scientific and practical points of view. A methodology for determining the rationality of subfederal level financing is proposed. A factorial model of the allocation of financial resources was developed and tested, and the regions and federal districts were typologized from the standpoint of rational financing of economic growth.
\end{abstract}

Keywords - rational financing, typology of regions, factorial model of financing, economic growth, economic development.

\section{INTRODUCTION}

The functioning of the economy is to some extent governed by the institutions creating and forming economic laws that determine the ways of the development of society. However, the question of how to achieve the necessary level of effectiveness of the institutional mechanism remains and needs scientific and practical comprehension. Participants of the economic process have to solve many complex socio-economic tasks; the most important one is to determine how to use limited financial resources in order to achieve certain development indicators.

In the context of solving the unique problem of transferring the socialist economy to the market one, it becomes urgent to create a mechanism for the development financing in the process of reforming the institutions of society, including finance and financing. The importance of the updating of these concepts is caused by various interpretations, developed both in the scientific area and in the public consciousness that has a direct impact on institutions.

The global economic crisis of 2008 and its comprehension led both scientists and politicians to change their perceptions about the role of the state in economic development. The crisis showed that the state is not only the highest political institution of society, but also the institution that bears full responsibility for the economic system. In all economies fallen into the crisis, it is the state that helped the financial sector and the real economy.

\section{GOAL OF THE RESEARCH}

The current economic situation in Russia also requires new approaches to evaluating the role of the state as an institution in economic processes and searching for instruments that enable it to effectively influence economic development. One of such instruments is rational financing. However, in the context of the crisis, the most important task of economic research is the selection of a rational financing mechanism that allows resources to be channeled into key, nationally significant development projects. The search and scientific justification of such a mechanism is the most important research and practical task.

As the economic situation is deteriorating due to world energy prices fall, it becomes obvious that countries having a one-sided export orientation are the most vulnerable during the crisis period, since their institutions are not formed according a mixed economy. The way out of this situation is the development of a self-sufficient national economy based on integrated development at the subfederal level. To solve the task of stimulating the integrated development of regions without dispersing the limited financial resources of the society will allow the introduction of rational financing. Transition to rational principles of financing at the level of the subjects of the Federation requires a thorough scientific justification. Thus, the development of theoretical and methodological foundations for rational financing of the integrated development of the subjects of the Russian Federation and the elaboration of recommendations for its implementation in the subjects of the Federation is an important scientific and practical task.

\section{METHODS OF THE RESEARCH}

We believe that with an unstable economic situation and limited financial resources, the existing financing system of the subfederal level requires to be changed, and rational financing will stimulate integrated development at the subfederal level. We agree with the opinion of Yu. G. Shvetsov that "one of the reasons for the slow development of finance in Russia is the underestimation of the scientific value and practical significance of the theories of institutionalism and modern neoinstitutionalism. It is these theoretical teachings that are the foundation of the successful functioning of Western financial institutions "[1]. 
We believe that the application of the process approach allows us to consider the financing of economic development as a continuous institutional process where economic actors participate. It is important to note that the study of the concept of "finance", conducted by Y.M. Bezrekin [2] [3], showed three fundamentally different types of finance: a Western European model of public finance; the Soviet model of public finance; a model of private finance. From the standpoint of Russian institutions, now we have a simultaneous existence of all three types of finances that undoubtedly affects the rates of economic growth and economic development.

Economic development is one of the most important targets for modern states. It should be noted that the very concept of economic development is used in various meanings, and often refers to economic growth. In our study, we consider it necessary to differentiate these concepts for the following reasons:

1. Economic growth is a quantitative indicator, reflected in GDP growth, GRP and other similar indicators.

2. Economic development is a qualitative indicator, which is of a process nature and reflects the transformation of the existing economic structure to the demands of the future.

Economic development includes economic growth, while development is not only growth, development can also be accompanied in some cases by economic decline, recession, and stagflation.

In case of developing economies, one should first focus on economic development, rather than on economic growth, since a decline of the economy, reflected in statistical data, can indicate the redistribution of available resources in order to create a new economic structure able to ensure its growth in the future. At the same time, the studies of A. Elekes and P. Galmai [4] taking Eastern European economies as an example showed that the model of economic growth and convergence, operated before 2008 , is not suitable nowadays.

The role of finance and financing in providing economic growth is ambiguous. Finance can not only contribute, but also hinder the growth of the economy [5]. Thus, the world financial centers are separated from the economy of a particular country in the world and follow goals that have nothing to do with economic development. A new study by Bank for International Settlements has shown why too rapid growth in the financial sector has a negative impact on the entire economy [6]. "Productivity in the financial-dependent sectors of the economy in countries experiencing a financial boom is generally $2.5 \%$ lower than in the financial-dependent sectors of the economy in countries where there is no such boom," the study said.

It is necessary to distinguish between economic growth and economic development from the standpoint of finance (Table 1).

The task of periodization based on the goals and sources of financing (Table 2) is solved that in its turn forms the instruments and the role of the state in these processes that has made it possible to formulate the concept of rational financing which should be used as a financial instrument at the present stage. We consider the prerequisites that necessitated the transition to this stage:

1) socio-economic consequences of the collapse of the USSR were completely formed that led to the necessity to form new supranational associations that will have different effects on certain regions of our country;

2) post-war division of the world does not suit the largest participants of the world financial system, which actively finance the changing in the role of regions and macro regions in the global formation of financial resources;

3) inequality of the economic development of some regions of the same country (Spain - Barcelona, Great Britain Scotland, Russia - Far East and Siberia);

4) the fact that in our country there are subjects of different levels of social and economic development, while the target points for them are incomparable (for example, Crimea and Sevastopol, the North Caucasus, Siberia and the Far East);

TABLE I. ROLE OF FINANCING IN ACHIEVING THE GOALS OF ECONOMIC DEVELOPMENT AND ECONOMIC GROWTH

\begin{tabular}{|l|l|l|}
\hline & \multicolumn{1}{|c|}{ Economic growth } & \multicolumn{1}{|c|}{ Economic development } \\
\hline Goal & increase of the volume of the economy & restructure of the economy \\
\hline Object & volume of the economy & structure of the economy \\
\hline Pubject & participants of the economic process & $\begin{array}{l}\text { state or communities interested in changing their } \\
\text { status }\end{array}$ \\
\hline Sources of financing & $\begin{array}{l}\text { the rejection of current consumption; } \\
\text { competitiveness, access to investment resources, } \\
\text { an effective financial mechanism }\end{array}$ & $\begin{array}{l}\text { development strategy, investment in innovation, R } \\
\text { and D, availability of gold and foreign exchange } \\
\text { households }\end{array}$ \\
\hline Indicators & $\begin{array}{l}\text { GDP growth, an increase in the price of resources, } \\
\text { a rise of the cost of labor, the availability of } \\
\text { capital, the population change }\end{array}$ & $\begin{array}{l}\text { production of new goods, new production } \\
\text { methods, new sales markets, changes in the } \\
\text { industry structure, technical and technological } \\
\text { progress, changes in the structure of employment }\end{array}$ \\
\hline Instruments & market mechanism and state regulation & $\begin{array}{l}\text { rational financing } \\
\text { special funds of the state and corporations }\end{array}$ \\
\hline
\end{tabular}


TABLE II. PERIODIC STAGES OF THE DEVELOPMENT FINANCING AT THE SUBFEDERAL LEVEL

\begin{tabular}{|c|c|c|c|c|c|c|}
\hline $\begin{array}{c}\text { stage } \\
\text { № }\end{array}$ & stage & period & goal & $\begin{array}{l}\text { source of } \\
\text { financing }\end{array}$ & instrument & $\begin{array}{l}\text { role of state } \\
\text { government }\end{array}$ \\
\hline 1 & trade finance & $\begin{array}{l}\text { XY } \\
\text { century } \\
\text { included }\end{array}$ & $\begin{array}{l}\text { seizure of sales } \\
\text { markets and control } \\
\text { over trade routes }\end{array}$ & $\begin{array}{l}\text { commercial } \\
\text { capital }\end{array}$ & expeditions & $\begin{array}{l}\text { military } \\
\text { support }\end{array}$ \\
\hline 2 & $\begin{array}{l}\text { financing of spatial } \\
\text { development }\end{array}$ & $\begin{array}{l}\text { XVI- } \\
\text { XYII } \\
\text { centuries }\end{array}$ & $\begin{array}{l}\text { creation of sales } \\
\text { markets and control } \\
\text { over resources }\end{array}$ & treasury & $\begin{array}{l}\text { strongholds, tax } \\
\text { breaks and } \\
\text { private armies }\end{array}$ & $\begin{array}{l}\text { military } \\
\text { support }\end{array}$ \\
\hline 3 & $\begin{array}{l}\text { financing of the } \\
\text { inclusion of regions in a } \\
\text { common economic area }\end{array}$ & $\begin{array}{l}\text { XYIII- } \\
\text { XIX } \\
\text { centuries }\end{array}$ & $\begin{array}{l}\text { inclusion of regions } \\
\text { in a common } \\
\text { economic area }\end{array}$ & industrial capital & $\begin{array}{l}\text { system of public- } \\
\text { private } \\
\text { partnership }\end{array}$ & regulation \\
\hline 4 & mobilization financing & $\begin{array}{l}1900- \\
1980 \\
\text { years }\end{array}$ & $\begin{array}{l}\text { creation of } a \\
\text { powerful diversified } \\
\text { industry }\end{array}$ & $\begin{array}{l}\text { households } \\
\text { savings }\end{array}$ & $\begin{array}{l}\text { centralized } \\
\text { distribution and } \\
\text { planning }\end{array}$ & $\begin{array}{l}\text { creation of } \\
\text { centralized } \\
\text { funds }\end{array}$ \\
\hline 5 & $\begin{array}{l}\text { financing development } \\
\text { centers }\end{array}$ & $\begin{array}{l}1981- \\
2010 \\
\text { years }\end{array}$ & $\begin{array}{l}\text { financing of } \\
\text { advanced industries }\end{array}$ & $\begin{array}{l}\text { international } \\
\text { finance }\end{array}$ & stock market & regulation \\
\hline 6 & rational financing & $\begin{array}{l}2011- \\
\text { present } \\
\text { time }\end{array}$ & $\begin{array}{l}\text { taking into } \\
\text { consideration the } \\
\text { typology of the } \\
\text { region }\end{array}$ & $\begin{array}{l}\text { public and } \\
\text { corporate } \\
\text { finance }\end{array}$ & $\begin{array}{l}\text { public-private } \\
\text { partnership }\end{array}$ & $\begin{array}{l}\text { stimulation } \\
\text { and } \\
\text { reproduction }\end{array}$ \\
\hline
\end{tabular}

most important task is the creation of socio-economic development conditions, taking into account the characteristics of the subjects of the Russian Federation, while rejecting the policy of random choice of regions "development centers". Our country needs to change the regional specialization formed in the USSR. Thus, a comprehensive study of the historical experience of financing of regional development shows the need for rational financing in achieving the development targets. Taking into consideration the historical experience of accumulation and targeted spending of financial resources, including attraction of large corporations and public-private partnerships, will contribute to the integrated development of Russian regions.

The next step is to formulate the methodological foundations of rational financing and its impact on the economic development of the subjects of the Federation. Financing can be considered as a process that ensures the implementation of one of the functions of finance, that is distribution. However, this is a narrow approach, representing a negative Soviet financial experience (when financing was often based on political decisions) and simultaneously a modern "pseudo-market" method (always assuming the economic effect, without taking into account the multiplier effect).

We believe that financing is the process of providing the reproduction process with cash and other assets.

The inclusion of "other assets" in the concept of "financing" is caused by the fact that financing means not only giving money, but also providing assets for certain purposes, as well as providing benefits (for example, maternity capital is created to stimulate fertility; and accelerated depreciation is aimed at fixed assets updating, etc.). Narrowing the general term of financing to "rational financing," we propose to define it as a process of providing money and other assets with
We agree with the view of Y.G. Shvetsova: "public financial resources can and should become a kind of catalyst for modernization of the economy and smoothing out excessive differences" [7].

Rational financing has its own peculiarities associated with economic, religious, cultural and other characteristics of the financial system. Consequently, it is impossible to form scientific views on rational financing without considering the genesis of this process.

Rational financing is an effective instrument for smoothing the emerging imbalances. At the same time, if the region is acting as an impact object, a number of features must be taken into account. In our opinion, modern financing of regional social and economic development has its own features:

1. A lot of sources that are both controlled at the regional level (regional and local budgets) and uncontrolled (state nonbudget funds, federal budget, customs bodies, national corporations).

2. Instability of structure and volumes [8], caused by constant changes in monetary and fiscal policy by the federal center.

3. Strongly expressed social orientation.

4. Normative regulation is under the control of the federal center.

5. Need to include regional objectives in federal priorities.

6. The personal responsibility of the regional authorities for the timely fulfillment of the promises of the federal center. 
7. Lack of linkage between the volume of regional financial resources and their assumed financial obligations [9].

Features of rational financing:

- monetary form or assets;

- targeted nature - ensuring expanded reproduction;

- presence of economic development;

- reduction of transaction costs.

Rational financing should meet the following principles:

1. The goal is clearly formulated and has certain characteristics (quantitative and qualitative) that are not divided into optimistic, pessimistic and realistic.

2. The participants of the project, their level and areas of responsibility, and, in addition, the system of financial sanctions for non-fulfillment of obligations are defined.

3. There is the necessary financial and other security at stable prices, the adjustment of which is unacceptable for the entire period of the project.

4. The sources of funding are identified and consolidated.

To determine the results of financing, it is necessary to determine how well it was implemented in previous years. We suggest using the methodology for determining the level of rationality of financing at the subfederal level based on the system of indicators. The rationality of financing the region needs to be assessed in the following way: it is proposed to distinguish several stages.

Stage 1 - the formation of development indicators in the following areas - demographic and labor indicators, social indicators, economic indicators, living standards of the population, infrastructure, financial. When choosing indicators, we were guided by the following principles:

1) accessibility and openness of information;

2) the exclusion of subjectivity in the assessment;

3) the coverage of all components of the integrated development of the region;

4) an equal number of indicators for each direction;

5) the possibility of linking the areas of rational financing and a specific indicator;

6) "all factors or phenomena, one way or another, are interrelated - directly or indirectly, implicitly or explicitly" (V.Z. Balikoyev) [10].

Stage 2. A comparison is made between the all-Russian indicator and the subfederal indicator.

(1),

$$
b_{i j}^{k}=\left\{\begin{array}{l|l|l}
0, & \text { All }- \text { Russia indicator } \\
1_{1} & >\text { regional indicator }_{i j}^{k} \\
\text { All }- \text { Russia indicator } & \leq \text { regional indicator }_{i j}^{k}
\end{array}\right\}
$$

where $-\mathrm{i}$ - category number $\varepsilon[1 ; 6] ;$

- $\mathrm{j}$ - indicator number $\varepsilon[1 ; 10]$;

- $\mathrm{k}$ - region of the Russian Federation; $-b_{i j}^{k}$ - rating of i-indicator $\mathrm{j}$-category k-region of the

Russian Federation;

$-S^{k}$ - weight according the category;

- $S_{i}^{k}$ - weight according the category.

$S_{i}^{k}=\sum_{i} b_{i j}^{k}$

Stage 3. Preparation of summary data for the period of 1990-2013 for each indicator separately, and then for the selected areas:

$$
S^{K}=\Sigma_{i} \Sigma_{j} b_{i j}^{k}
$$

Stage 4. Determining the rationality of financing at the subfederal level of the Russian Federation.

Stage 5. Creating of a rationality rating of financing at the subfederal level of the Russian Federation.

The rationality of financing of the federal districts (FDs) for the period 1990-2013 is analyzed, and their rating is formed (Figure 1) by sixty indicators, organized in six directions [11]. As the North-Caucasian and Crimean Federal districts exist for a short period of time, relatively to the initial date of the analysis, we left the first FD in the Southern FD (all administrative subjects of the Federation were initially divided into two FDs) and we did not consider Crimean FD, since the Russian Federation had no relation to financing it until 2014. Consequently, in the analyzed period the Crimean Federal District did not officially exist.

As can be seen (Figure 1), the leaders are the Central and North-Western FD, the outsiders are the Volga and Southern FDs, and the rationality of their funding differs by almost half, that contributes to the growth of social problems and negative socio-economic consequences for the Russian Federation in whole.

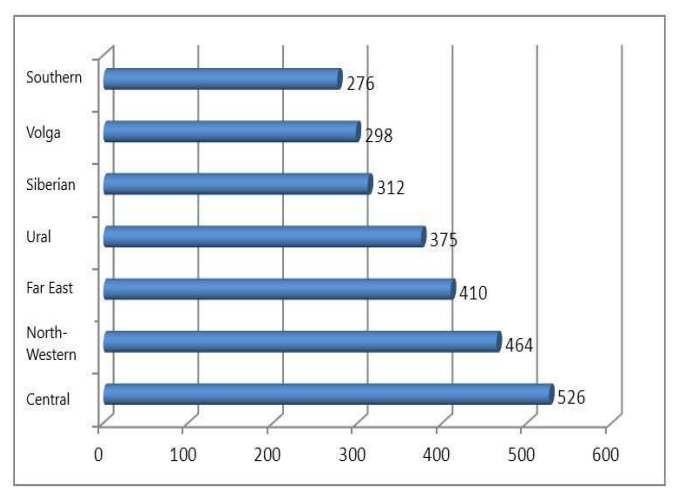

Fig.1. Rating of rationality of financing at the level of federal districts (in points) 
This indicates that the socio-economic living conditions and the performance of entrepreneurial activities for Russian citizens in various districts are not comparable during the period under review [12].

Consequently, the main reason for the current situation is not the amount of funds allocated, but an irrational approach to the financing.
We consider then the rationality of financing of the Siberian Federal District (Figure 2) that importance as a source of natural resources can not be overestimated, taking into account the modern structure of the Russian economy.

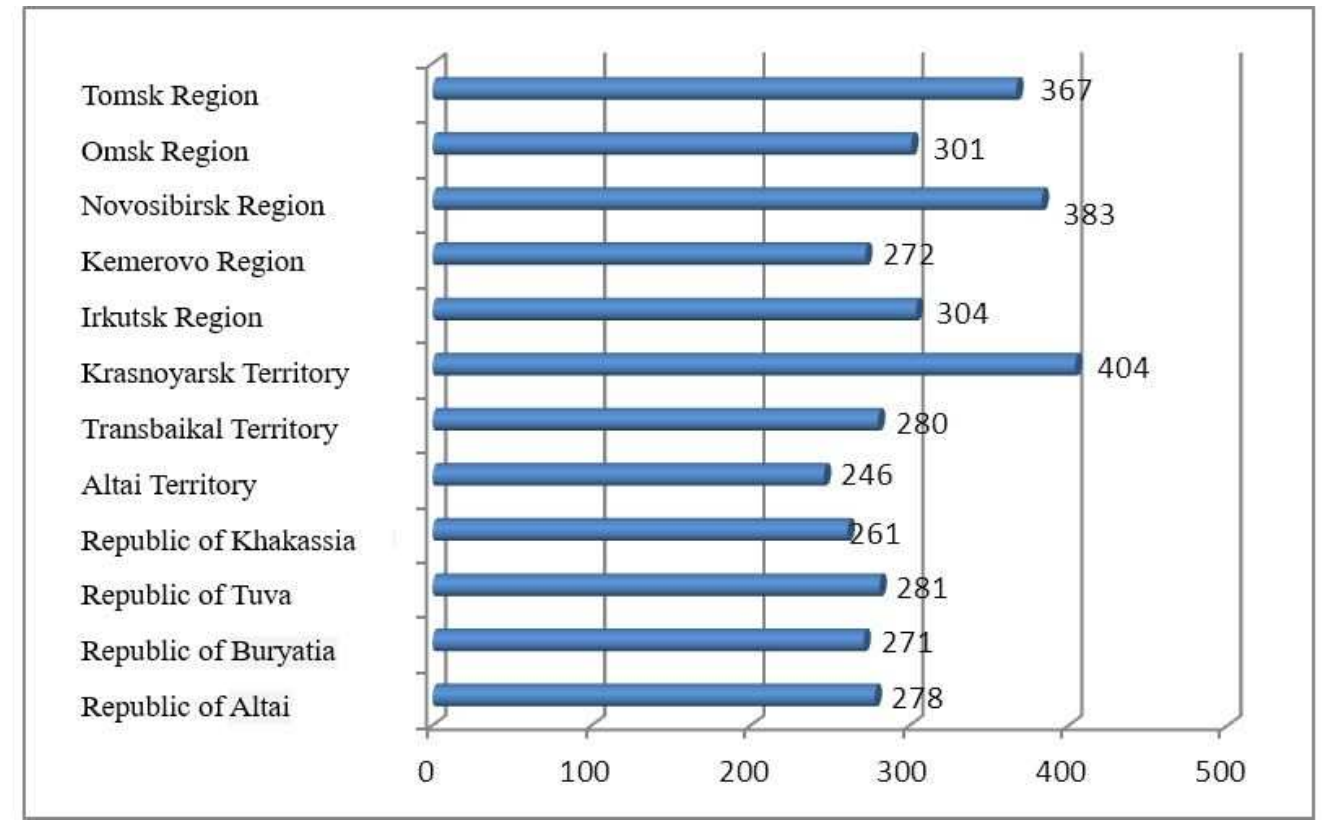

Fig.2. Comparison of the rationality of financing for the period 1990-2013 in the Siberian Federal District

As can be seen from the data on the rationality of financing in the Siberian Federal District (Figure 2), there is a very large gap - about $40 \%$ between the Altai Territory with its 246 points and the Krasnoyarsk Territory with 404 points, which certainly reflects the existing difference in the efficiency of rational financing, aimed at equalizing the living conditions of citizens of the country in its various regions. We believe that in this particular macroregion, the development center, the Krasnoyarsk Territory, is being formed that will contribute to the outflow of all resources, including financial resources, to this constituent entity of the Federation. The attention should be paid to the Novosibirsk region, which is slightly behind the leader, but by a very important indicator - the standard of living. This lag is almost two times that can play a decisive role in the outflow of population from the Siberian regions.

Hence, there is a need to propose approaches to the implementation of rational financing at the subfederal level. To solve this problem, a factorial resource allocation model was developed for rational financing at the subfederal level based on statistical data for the period 2000-2014 in the context of federal districts and subjects of the federation. On basis of this model, the typology of regions and federal districts has been specified.

In our research, we considered a parametric model. When analyzing the per capita GRP (endogenous factor y), it depends on the exogenous variables $\mathrm{x}_{1}, \mathrm{x}_{2}, \ldots \mathrm{xm}$.

TABLE III. FACTORS AFFECTING GRP

\begin{tabular}{|c|c|c|}
\hline $\begin{array}{l}\text { Varia } \\
\text { bles }\end{array}$ & Characteristic & $\begin{array}{c}\text { Organizational form } \\
\text { of monetary } \\
\text { relations } \\
\end{array}$ \\
\hline $\mathrm{x}_{1}$ & expenditures of the regional budget per capita (thousands of rubles per year/a person) & \multirow{3}{*}{ Public finance } \\
\hline $\mathrm{x}_{2}$ & expenditures of the state non-budgetary funds per capita (thousands of rubles per year/a person) & \\
\hline $\mathrm{x}_{10}$ & public servants share ( $\%$ of the total population of the subject of the Federation) & \\
\hline $\mathrm{x}_{3}$ & fixed capital investment per capita (thousands of rubles per year/a person) & \multirow{3}{*}{ Corporate finance } \\
\hline $\mathrm{x}_{4}$ & capital-labor ratio (thousands of rubles per year/a person) & \\
\hline $\mathrm{X}_{5}$ & demography of organizations & \\
\hline
\end{tabular}




\begin{tabular}{|c|l|c|}
\hline $\begin{array}{c}\text { Varia } \\
\text { bles }\end{array}$ & \multicolumn{1}{|c|}{ Characteristic } & $\begin{array}{c}\text { Organizational form } \\
\text { of monetary } \\
\text { relations }\end{array}$ \\
\hline $\mathrm{x}_{6}$ & freight shipping by rail (millions of tons) & \\
\hline $\mathrm{x}_{7}$ & per capita income per year (thousands of rubles per year/a person) & \multirow{2}{*}{ Households finance } \\
\hline $\mathrm{x}_{8}$ & employment rate (\% on average for the year) & \\
\hline $\mathrm{x}_{9}$ & level of economic activity (\%on average for the year) & \\
\hline
\end{tabular}

As a result of applying the factor model, the following results were obtained (Table 4).

The analysis of the factors influencing the economic growth of the subjects of the Russian Federation (Table 5) showed that various factors have both a positive and negative impact on economic growth in relation to a specific subject of the subfederal level. At the same time, the demographic factor of organizations $x_{5}$ did not have any impact in any entity, which indicates that the number of small and medium-sized enterprises does not influence economic growth.

TABLE IV. FACTOR MODEL OF FINANCING OF ECONOMIC GROWTH OF SUBJECTS OF THE FEDERATION, INCLUDED IN THE SibERIAN FEDERAL DisTRICT FOR THE PERIOD OF 2000-2014

\begin{tabular}{|c|c|}
\hline Federal District & Model \\
\hline Central & $\mathrm{y}=-1,05 \mathrm{e}^{5}+3,49 \mathrm{x}_{2}+5,61 \mathrm{x}_{3}-42,9 \mathrm{x}_{4}-0,321 \mathrm{x}_{7}+1,74 \mathrm{e}^{5} \mathrm{x}_{10}$ \\
\hline North-Western & $\mathrm{y}=-1,10 \mathrm{e}^{05}+2,46 \mathrm{x}_{1}+129 \mathrm{x}_{4}+709 \mathrm{x}_{6}$ \\
\hline Southern & $\mathrm{y}=-2,37 \mathrm{e}^{4}+5,72 \mathrm{x}_{1}-55,9 \mathrm{x}_{4}+598 \mathrm{x}_{6}$ \\
\hline North-Caucasian & $\mathrm{y}=-1,40 \mathrm{e}^{4}+1,04 \mathrm{x}_{1}+2,14 \mathrm{x}_{2}+1,30 \mathrm{e}^{3} \mathrm{x}_{6}$ \\
\hline Volga & $\mathrm{y}=-359895-3,858 \mathrm{x}_{1}+3,132 \mathrm{x}_{3}+177,46 \mathrm{x}_{4}+156,33 \mathrm{x}_{6}+180,64 \mathrm{x}_{8}+4899,94 \mathrm{x}_{9}$ \\
\hline Ural & $\mathrm{y}=-3,43 \mathrm{e}^{5}+1,80 \mathrm{x}_{1}+4,81 \mathrm{x}_{2}+1,35 \mathrm{e}^{03} \mathrm{x}_{6}+2,68 \mathrm{e}^{5} \mathrm{x}_{10}$ \\
\hline Siberian & $\mathrm{y}=-1,03 \mathrm{e}^{5}+2,40 \mathrm{x}_{2}+1,21 \mathrm{x}_{3}+258 \mathrm{x}_{6}+4,56 \mathrm{e}^{4} \mathrm{x}_{10}$ \\
\hline Far East & $\mathrm{y}=-2,56 \mathrm{e}^{4}+3,45 \mathrm{x}_{2}+0,786 \mathrm{x}_{3}+32,7 \mathrm{x}_{4}+0,0567 \mathrm{x}_{7}+3,45 \mathrm{e}^{04} \mathrm{x}_{10}$ \\
\hline
\end{tabular}

Going to the regional level, let us consider the factors from the position of their influence on GRP growth (Table 5).

TABLE V. ANALYSIS OF FACTORS BY THE SUBJECTS OF THE FEDERATION FOR THE PERIOD 2000-2014

\begin{tabular}{|c|c|c|c|c|c|c|c|c|c|c|c|}
\hline Indicator & $\mathrm{x}_{1}$ & $\mathrm{x}_{2}$ & $\mathrm{x}_{3}$ & $\mathrm{x}_{4}$ & $\mathrm{x}_{5}$ & $\mathrm{x}_{6}$ & $\mathrm{x}_{7}$ & $\mathrm{x}_{8}$ & $\mathrm{x}_{9}$ & $\mathrm{x}_{10}$ & $\begin{array}{c}\text { Number of } \\
\text { factors }\end{array}$ \\
\hline $\begin{array}{c}\text { The number of positively } \\
\text { influencing factors (excluding } \\
\text { FD) }\end{array}$ & 21 & 24 & 26 & 19 & 0 & 17 & 29 & 15 & 7 & 11 & 169 \\
\hline $\begin{array}{c}\text { The number of negatively } \\
\text { influencing factors (excluding } \\
\text { FD) }\end{array}$ & 9 & 12 & 18 & 15 & 0 & 17 & 16 & 6 & 18 & 19 & 130 \\
\hline Total number of factors & 30 & 36 & 44 & 34 & 0 & 34 & 45 & 21 & 25 & 30 & 299 \\
\hline$\%$ of positive impacts & 26,3 & 30,0 & 32,5 & 23,8 & 0,0 & 21,3 & 36,3 & 18,8 & 8,8 & 13,8 & $21,1 \%$ \\
\hline$\%$ of negative impacts & 11,3 & 15,0 & 22,5 & 18,8 & 0,0 & 21,3 & 20,0 & 7,5 & 22,5 & 23,8 & $16,3 \%$ \\
\hline
\end{tabular}

Having studied the results of the influence of factors (Table 5), we should focus on the following: 1) the demography of organizations is a factor that does not have any impact, therefore, the support of small and medium-sized businesses has no effect on economic growth (perhaps because of the "shadow" market), but performs a purely social role ensuring employment of the population (most likely even selfemployment );

2) the freight shipping by rail has an equal positive and negative impact on economic growth - this is due to the export orientation of the Russian economy with a predominance of goods with a low level of processing (raw materials) and as a result of the small added value in them;

3) the level of economic activity has a negative impact, due to the mass evasion of self-employed citizens from paying taxes and the circulation of their financial resources outside the official structures, it also contributes to the formation of a "shadow" financial sector;

4) the share of civil servants - a negative factor indicates that if the region has reached the level of a quasi-state, a 
further increase in their number "hinders" economic development due to the increased administrative burden on the economy.

Undoubtedly, the obtained data require the development of specific recommendations, which we will do below by the example of the Siberian Federal District.

Leading Russian scientists are trying to identify regions as socio-economic entities. So A.G. Granberg [13] considers the most widespread four paradigms of regions: region-quasi-state; region-quasi-corporation; region-market; region-society.

Each of these paradigms deserves a separate consideration. Studying regions as quasi-states in the context of enlarging the regions (the Krasnoyarsk Territory, the Irkutsk Region, the Trans-Baikal Territory, etc.) and the formation of federal districts (and this process is incomplete, as evidenced by the creation of the North Caucasus and Crimean Federal Districts) is of great importance. At the same time, it can precipitate further disintegration of the Russian state. From the economic point of view, such an approach provides for a sufficiently independent financial policy, which, in the conditions of the world economy, makes the region extremely vulnerable to global players. From a financial point of view, it presupposes the availability of own resources and the relative independence of fiscal and monetary policy. Given the fundamental differences between the Russian regions (we proved above in calculating the rating of regions), the application of this approach is possible only to a limited extent, namely from the position of state funding, which is reasonable to divide into social and target.

The approach to regions as quasi-corporations comes from their possession of the potential (resource, natural, production, financial, infrastructure, etc.), which is sufficient for selfdevelopment. However, in modern economic conditions, the possibility for Russia to use this potential is lacking, since the bulk of the property complex is transferred to private hands, and the regions have a property complex of social and housing and communal infrastructures that are difficult to use as a source of economic development. On the contrary, these infrastructures require significant investments, and without reliable functioning of housing and communal services, vital activity in natural and climatic conditions (for example, Siberia and the Far East) is impossible. Hence, the competitive struggle for resources and profit is noted. At the same time, from the financial point of view, considering the region as a quasicorporation allows us to apply the targeted approach, while stimulating economic development.

Consideration of the region as a market is of great interest; however, the proximity of some regions to the rapidly developing China puts them in a position incomparable with the central regions of the country. With relation to the global financial market, Russian regions are turning into peripheral raw material appendages and markets for products that are not improving the efficiency of the economy, but aimed at meeting the current needs of the population (for example, the introduction of sanctions in 2014 for high-tech equipment). From the financial point of view, the application of this approach can lead to the "financial dying" of certain regions. As an example, we can mention the regions adjacent to the city of Moscow that residents work for the integrated development of the capital of our Motherland.

The approach to the region as a society (community of people living in a certain territory) in the presence of mononational regions and regions of cohabitation does not allow us to work out general management principles based on this approach.

Taking into account that Russia possesses high quality labor resources, there is a danger of an outflow of population to regions with higher wages (Moscow and St. Petersburg have accumulated such financial resources that "attracts" the population not only from other regions of the country, but also from the near abroad). However, from the perspective of financing, the society is the basis of integrated development and at the same time its goal. Based on the application of the factor model, regions can be divided into the following types (Table 6).

TABLE VI. TYPES OF REGIONS BY FACTORS AFFECTING GRP

\begin{tabular}{|c|c|}
\hline Type of the region & Factors affecting GRP \\
\hline $\begin{array}{l}\text { region-quasi- } \\
\text { corporation }\end{array}$ & $\begin{array}{l}\mathrm{x}_{3}-\text { fixed capital investment per capita (thousands of rubles per year/a person) } \\
\mathrm{x}_{4}-\text { capital-labor ratio (thousands of rubles per year/a person) } \\
\mathrm{x}_{5}-\text { demography of organizations } \\
\mathrm{x}_{6}-\text { freight shipping by rail (millions of tons) }\end{array}$ \\
\hline region-quasi-state & $\begin{array}{l}\mathrm{x}_{1}-\text { expenditures of the regional budget per capita (thousands of rubles per year/a person) } \\
\mathrm{x}_{2}-\text { expenditures of the state non-budgetary funds per capita (thousands of rubles per year/a person) } \\
\mathrm{x}_{10}-\text { public servants share }(\% \text { of the total population of the subject of the Federation) }\end{array}$ \\
\hline region-society & $\begin{array}{l}\mathrm{x}_{7}-\text { per capita income per year (thousands of rubles per year/a person) } \\
\mathrm{x}_{8}-\text { employment rate (\% on average for the year) } \\
\mathrm{x}_{9}-\text { level of economic activity (\%on average for the year) }\end{array}$ \\
\hline
\end{tabular}

From our point of view, the region-society concept can include the concept of region-market, since the market is the result of interaction of three parties: the state, business community and society, and it always exists (at least from the moment of division of labor). 
It is a region-society that appears the first when the territory is developed, while the infrastructure is still absent; a subsistence economy is formed, and economic ties in the society are extremely weak. In this case, state financing primarily needs to provide social support aimed at the formation of the society, and it should be implemented not through the regional and local budgets, but by the program-target method and have the following directions: medicine, education, housing and communal services and infrastructure. In fact, in this case, direct government operates while minimizing the financial rights of lower-level government bodies (direct presidential rule).

As the territory develops, a quasi-state region emerges that has a developed society capable of putting forward its leaders who are aware of the responsibility for regional development and who are going to live and work in the territory. In this case, state social financing can be transferred to the regional level, and for economic development. A development corporation should be created that will form the business community (it is not present at this stage, which is typical for the regions of Siberia, the Far East, and the North Caucasus). This level of development presupposes an increase in the influence of state funding on the formation of GRP. Consolidation of the business community and their awareness of their role for regional integrated development lead to the emergence of a quasicorporation region, in the presence of which it becomes a subject of economic life and is able to independently carry out economic development. Analyzing factors affecting GRP (per capita), it is possible to typology the regions. Otherwise, the implementation of a single regional policy in conditions of a complex Russian "organism" is impossible. The approach to the region as a separate subdivision of the state, taking into account its type depending on funding, contributes to the scientific and practical formulation of the principles of governing it as an object in the global economy.

\section{CONCLUSION}

The implementation of the factor model has made it possible to determine directions for each subject of the Russian Federation that can increase economic growth. The model allows estimating the results of economic growth as a result of increasing the volume of financing, as well as its decrease in case of negative influence of the factor. It will make it possible to formulate a policy of state financing at the sub-federal level, including optimizing the use of limited financial resources. The above list of strategies is not exhaustive, e.g. A.V. Novikov distinguishes three strategies for Russia: globalization, borrowing the institutions of Western civilization through their adaptation and the national form of modernization [14].

The typology, depending on factors influencing GRP, of the subfederal level is proposed: regions-quasi-corporations - 44, regions-quasi-states - 23, regions-society-13, not defined - 2 .

Having analyzed factors in the context of federal districts and subjects of the Federation, the following conclusions can be drawn:

- subjects of the Russian Federation are at different levels of integrated development;
- homogeneity of factors influencing economic growth is not observed even within the federal district;

- specific factor affects the GRP growth in the region both positively and negatively (Table 5) that proves the impossibility of a unified approach to financing in the Russian Federation.

- Federal districts are formed arbitrarily and this fact does not contribute to the growth of rationality of financing.

Adjustment of development financing at the subfederal level is possible on the basis of classification of the constituent entities of the Russian Federation and transition to rational financing.

\section{References}

[1] Yu. G. Shvetsov, V.G. Koreshkov, "Commercial bank as the main link in the financial system of the Russian Federation," Financial analytics: problems and solutions, Vol.22 (208), pp. 2-7, 2014.

[2] Yu. M. Berezkin, Historical Types of Finance: Methodological Analysis, Irkutsk: ISEA Publishing House, 2000, pp. 18-24.

[3] Yu. M. Berezkin, Problems and ways of organizing finance, Irkutsk: ISEA Publishing House, 2001.

[4] A. Elekes, P. Halmai, "Growth model of the new member states: Challenges and prospects," Intereconomics, Hamburg, Vol. 48, No. 2, pp. 124-130, 2013.

[5] V.M. Gerasimov, F.R. Grigoryan, Contradictions of financial interaction between the banking and real sectors of the economy of modern Russia, Moscow: Dashkov and K., 2014.

[6] "The Economist: a financial boom impedes economic growth", [Electronic resource], URL:http://www.vestifinance.ru/articles/53638.

[7] Yu.G. Shvetsov, O.A. Bulash, "Financial foundations of the formation in Russia of a socially-oriented budget," Accounting in budgetary and non-profit organizations, Vol. 9 (345), pp. 28-39, 2014.

[8] "Consolidated budget of the Russian Federation and budgets of state non-budget funds in 2014 (billion rubles). According to the Federal Treasury", [Electronic resource], URL: http://www.gks.ru/free doc/new_site/finans/fin21.htm.

[9] "Execution of the consolidated budget of the constituent entity of the Russian Federation in 2014", Rossiyskaya Gazeta on March 10, 2015. [Electronic resource]. URL: http://www.rg.ru/printable/2015/03/10/statistika-dok.html.

[10] V.Z. Balikoev, "Phillips curve: myth or reality?", Economics, pp. 3 10. May-June. - 2012.

[11] V.A. Bubnov, Formation of economic attractiveness of the Siberian Federal District: monograph, Irkutsk: Publishing House of IrGUPS, 2009.

[12] V.A. Bubnov, "Methodology for determining the economic attractiveness of the federal districts of the Russian Federation," Modern technologies. System analysis. Modeling, No. 1 (33), pp.291295, 2012.

[13] A.G. Granberg, Fundamentals of Regional Economics, 3rd ed, Moscow: State University Higher School of Economics, 2003.

[14] A.V. Novikov, "National formula of modernization for the Russian economy," Economics. Scientific notes, Vol. 27, pp.196-201. 